\title{
Factors Influencing Customers' Adoption of Online Banking Services (With Special Reference to NEFT, RTGS, IMPS)
}

\author{
C. B. Pavithra, A. C. Ranganayaki
}

\begin{abstract}
The new millennium has unveiled numerous opportunities in information and communication technology and has generated magnificent impact in Banking Sector. Banking scenario has been changed rapidly since 1990's. Anywhere and anytime banking has become the reality. It provides the opportunity to harness technological power to handle vast transactions quickly and more efficiently and especially with less man power. Online banking has become very much popular nowadays throughout the globe. The banking industry recognizes that online transaction must be secure to achieve a high level of confidence with both clients and business. In India, banks are offering online banking services to embrace with tech savvy generation, demanding modern technology based banking systems. This is fast changing the way you bank. Educated people with access to the online are in the forefront of this technology driven revolution. Nowadays, banking services are delivered online since it has become the need of the hour. This is an empirical study, conducted to examine the factors influencing customers to adopt online banking services and to measure their level of satisfaction.
\end{abstract}

Keywords : Online Banking, Convenience, Security, Ubiquitous, NEFT, RTGS, IMPS.

\section{INTRODUCTION}

$\mathrm{T}$ echnology reformation has bought in the evolution of banking products and services in an innovative way with efficient processing channel and speedy delivery of products and services in the banking industry. Online banking transactions can be done electronically without visiting a brick-and-mortar institution. Online Banking is ubiquitous today that customers demand online banking services to be available at free of cost. Banks are efficiently delivering online services, by offering services at an optimum price to meet up the competition and minimizing the overheads cost, to gain higher profits. Morais states that, In case of an online banking, banks need not to have branches, but can offer innovative services to customers $24 / 7$ and provide competitive products at mediocre rates.

\section{A. Online Banking}

Performing banking activities in the bank's secured website is termed as online banking. Online banking allows a

Revised Manuscript Received on December 05, 2019.

* Correspondence Author

C. B. Pavithra*, Research Scholar, Ph.D-Commerce. SDNB Vaishnav College for Women, Chromepet, Chennai, India.

Dr. A. C. Ranganayaki, Assistant Professor, Research Department of Commerce. SDNB Vaishnav College for Women, Chromepet, Chennai, India. user to execute financial transactions via internet. Services which were traditionally performed in the bank branch are now available on the web for customers. Netizens have started opting social media and mobile apps for most of the banking transaction mainly because transfer of funds can be done in a fraction of time. However, for high value transactions it is advisable to use online banking facility which is more reliable and safer that carrying hard cash.

Online banking is also known by various terms such as: Internet banking, electronic banking, net banking, virtual banking and cyber banking. The financial transactions can be done by the customers themselves with the help of bank's website. Online banking enables its customers (individual persons or corporates) to access their accounts online. With the help of computers, laptops, smartphones and internet connection users can $\log$ in their account and enter the password to check their account details, balance in various accounts, and transfer of funds (inter-bank and intra-bank), make payments for various utility bills, taxes, insurance premium and also for their online purchases. The transactions are completed securely in bank website only after authentication.

Origin: In 1980, it was the United American Bank, was the first bank to offer online internet banking services, in the USA. Then by 1996, in India the first bank to introduce internet banking was the ICICI Bank.

There are three different ways of online banking fund transfers such as RTGS, NEFT and IMPS. NEFT, RTGS, IMPS are the methods used to transfer money from one account/bank to another account/bank within India. NEFT and RTGS systems are maintained by central bank i.e., Reserve Bank of India and IMPS is managed by the National Payments Corporation of India (NPCI)

NEFT: National Electronic Funds Transfer is a payment system which facilitates funds transfer using bank's website. In India, NEFT is one of the well-known electronic funds transfer system with which funds can transferred via electronic messages, effortlessly and also securely. NEFT is cleared on an hourly basis hence this results in time lag. RBI explains this scheme as NEFT is a nation-wide payment system facilitating one-to-one funds transfer. For Companies, firms, individuals, now it's possible for fund transfer electronically from any bank branch to any individual, company, firm or corporate having an account with any other bank branch in the country. 
$\square$ NEFT transactions are available from 08:00 am to 07:00 pm on weekdays and on Saturdays expect 2nd and 4th Saturdays, Sundays and on Public Holidays.

$\square$ NEFT are used to transfer funds from a Minimum of Re. 1 to a Maximum of Rs.2 Lakhs, and its charges ranged between Rs.2.50 to Rs.25.

$\square$ Earlier there were transaction fees for NEFT but on 6th of June 2019, RBI declared that charges will be waived for banks and customers from 1st July 2019.

Origin: In India the National Electronic Fund Transfer started from November 2005. The Institute for Development and Research in Banking Technology (IDRBT) was established to maintain the NEFT setup. IDRBT was established by Reserve Bank of India in 1996, to focus exclusively on banking technologies.

RTGS: Real-Time Gross Settlement is an expert system to transfer of funds or securities from one bank to other bank on a real time basis and instantly without any waiting time. The transfer once processed, payments are final and non-recoverable. Usually, RTGS transfers are used for high-value transactions that necessitate immediate clearing. RTGS is maintained, operated and controlled by Reserve Bank of India.

RTGS transactions are available from 08:00 am to 08:00 pm on weekdays and on Saturdays expect 2nd and 4th Saturdays, Sundays and on Public Holidays.

RTGS are used the transfer funds from a Minimum of Rs. 2 Lakhs to a Maximum no limit, and its charges ranged between Rs. 25 to Rs.55.

$\square$ Earlier there were transaction fees for RTGS but on 6th of June 2019, RBI declared that charges will be waived for banks and customers from 1st July 2019.

Origin: In 1975, the US Fedwire system initially launched Real Time Gross Settlement. In India the Real Time Gross Settlement started from 2004 by the central bank, RBI.

IMPS: Immediate Payment Service is a prompt real-time and inter-bank electronic funds transfer system in India and is managed by the National Payments Corporation of India (NPCI). Using this service, we are able to receive or send Holidays, RBI Holidays. The money is credited into the beneficiary account instantly. IMPS offer an inter-bank electronic fund transfer service through mobile phones, laptops, computers, etc. In contrast to NEFT and RTGS, this service is accessible 365/24/7 and without any transaction charges.

Origin: The Immediate Payment Service system was inaugurated on 22nd November 2010 by National Payment Council of India.

\section{REVIEW OF LITERATURE}

Hua (2009) In this paper the researcher aimed to investigate the adoption of online banking by users in China. The study reports that there is a positive impact on the perceived ease of use and specific privacy policy with the acceptance of online banking, and security is treated as the money even on 2nd and 4th Saturdays, Sundays, and Public

dominating factor affecting online banking usage. Hence perceived case of use, privacy and security play an important role for the adoption of online banking. This study found that online shopping is highly correlated with the adoption on online banking. The researcher enunciates that online shopping and online banking are the integral part of e-commerce. This study concludes that once privacy and security concerns are relieved then the users' acceptance and adoption of online banking will grow exponentially.

Vichuda \& Ekin (2001) In an exploratory study, the researchers have aimed to empirically investigate the acceptance of internet banking services by the Turkish consumers. This study has examined the consumer related factors as well as organisational factors that affect the adoption of internet banking. The findings of the study reveals that factors like accessibility, reliability and savings are predominant for the satisfaction of consumers and factors like marking efforts and competition are important for organisations. It is suggested that banks must effectively handle the complaints of consumers and prevent them from migrating towards competitors. The researchers conclude that internet banking reduces the operating cost for banks and helps to achieve customers' satisfaction and also to retain customers.

Laforet \& Li (2005) The researchers targeted to examine the consumers' attitude towards online and mobile banking in China. This study revealed that unlike other country respondents the Chinese consumers did not consider convenience, ease of use, anytime-anywhere banking; rather they were motivated by the issue of security as a main factor for the adoption of internet banking. The obstacles of online banking were lack of computer and technical skills, perception of risk and the habit of using cash. Then, the hindrances for adopting mobile banking were the lack of awareness and the lack of knowledge about the benefits of mobile banking. The researchers suggest that bankers should provide awareness messages through advertising and other sources to encourage consumers to adopt online and mobile banking.

Awamleh \& Fernandes (2005) The researchers aimed to study the determinants that affect the consumers' intention to adopt internet banking in UAE. The empirical analysis of the study showed that convenience, securities are significant and independence is insignificant for the consumers' satisfaction towards internet banking. It states that internet banking in UAE is at infant stage hence, suggested that improvements should be made in design, infrastructure and interface of internet banking and incentives should be provided to grasp customers to adopt internet banking services.

Yiu et al. (2007) The researchers targeted to identify the current usage rate of internet banking and explored the factors related to the adoption of internet banking. The result of the study depicts that internet banking adoption is being strongly associated with perceived usefulness, moderately associated with perceived ease of use, perceived risk and weakly associated with personal innovativeness in information technology.

Published By:

Blue Eyes Intelligence Engineering

26 \& Sciences Publication 
They have given various implications to banks for the development of services to enhance the usage of internet banking by the customers.

\section{OBJECTIVES}

To understand the concept of online banking services especially with regard to RTGS, NEFT, IMPS.

$\square$ To identify the factors influencing customers to adopt online banking services and to measure their level of satisfaction.

$\square$ To offer suggestions to improve the online banking services.

\section{RESEARCH METHODOLOGY}

This study is descriptive in nature. The present study is primarily focused on identifying the factors influencing customers to adopt online banking services over conventional banking.

Data collection: Primary data consist of original information collected for specific purpose of online banking users of different age groups and gender. Secondary data comprises of information that already available somewhere that has been collected for this purpose. The secondary data is obtained from the text book, research articles, journals and online sources.

Sampling design and size: Under this study, convenience sampling is used for selecting the sample from the universe. The questionnaire has been issued to 150 respondents in Chennai City.

Questionnaire Structure and Design: A Structured questionnaire was used to collect the primary data. The Questionnaire is divided into two parts.

Part I deals with the general information about the respondents.

Part II relates to the online banking services.

Statistical analysis: The data that was collected were statistically analysed through Percentage Analysis, Garrett Ranking, Factor Analysis and ANOVA using SPSS.

\section{ANALYSIS AND FINDINGS}

Analysis and findings is a process of assessing meaning to the collected information and determining the inference of the study.

Percentage Analysis: This percentage analysis was used identify the distribution of respondents on the basis of their demographic and banking profile.

Percentage Analysis $=\frac{\text { NUMBER OF RESPONDENTS }}{\text { TOTAL NUMBER OF SAMPLES }} \times 100$

\section{Respondents - Demographic Profile}

In this study, Majority of the respondents are-----

$\square$ Female $(94 \%)$

$\square$ In the age group of $21-30$ years $(68.7 \%)$. They are using online banking services frequently.

$\square$ Unmarried in this study (93\%)

$\square$ Post Graduates (46\%)

$\square$ Self-employed or business personal who are facilitated online banking services (38\%) $\square$ Earning between 1-3 Lakhs as their annual income $(34.7 \%)$

\section{Online Banking Activities}

Most of the respondents -----

$\square$ Hold their accounts in private sector banks in this study $(49.3 \%)$

$\square$ Maintain savings bank account $(89.3 \%)$

$\square$ Prefer online banking access Always (35.3\%)

$\square$ Access online banking facility in iPads/tablets/mobile $(58.7 \%)$

$\square$ Transact online banking through banking websites $(67.3 \%)$ than on bank apps $(32.7 \%)$

$\square$ Are using online banking facility for $3-5$ years $(52 \%)$

$\square$ Prefer to transfer money (73\%)

$\square$ Agree that online banking information system is trustworthy and useful $(89 \%)$

$\square$ It is to be noted that none of the respondents are dissatisfied of online banking activities. Most of the respondents are satisfied with online banking services $(63.3 \%)$

\section{1(a) Percentage Analysis on Customers' Preference of Online Transfer}

Table-4.1(a) Preference of Online Transfer

\begin{tabular}{|c|c|c|c|}
\hline $\begin{array}{c}\text { Preference of } \\
\text { Online Transfer }\end{array}$ & NEFT & RTGS & IMPS \\
\hline Always & $25(16.7 \%)$ & $29(19.3 \%)$ & $76(50 \%)$ \\
\hline Often & $33(22 \%)$ & $59(39.3 \%)$ & $46(30 \%)$ \\
\hline Sometimes & $62(41.3 \%)$ & $35(23.3 \%)$ & $26(17.3 \%)$ \\
\hline Rare & $14(9.3 \%)$ & $15(10 \%)$ & $2(1.3 \%)$ \\
\hline Never & $16(10.7 \%)$ & $12(8 \%)$ & - \\
\hline Total & $150(100 \%)$ & $150(100 \%)$ & $150(100 \%)$ \\
\hline
\end{tabular}

Chart-4.1(a) Preference of Online Transfer

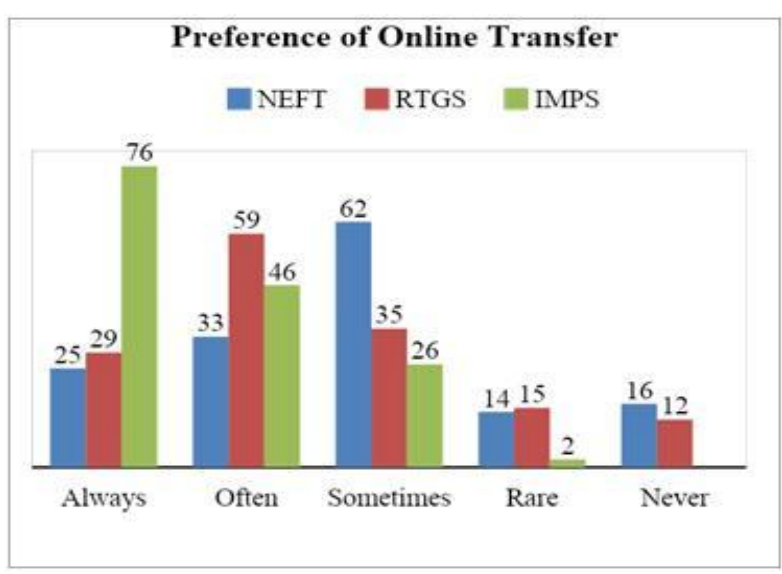

Source: Primary Data

Interpretation: The customers can transfer funds using the online banking services such as NEFT, RTGS and IMPS. From table 4.1(a), it is clear that out of 150 respondents, 
- With regards to NEFT $16.7 \%$ of the respondents are using always, $22 \%$ of them are using often, $41.3 \%$ of the respondents are using sometimes, $9.3 \%$ of them are using rarely and $10.7 \%$ of the respondents have not used NEFT.

- With regards to RTGS, $19.3 \%$ of the respondents are using always, $39.3 \%$ of the respondents are using often, $23.3 \%$ of the respondents are using sometimes, $10 \%$ of them are using rarely and $8 \%$ of them have not the RTGS services.

- With regards to IMPS, $50.7 \%$ of the respondents using always, $30.7 \%$ of them are using often, $17.3 \%$ of the respondents are using sometimes and only $1.3 \%$ of them are using rarely. Hence, it is conclude that though the IMPS system is technically new to India, most of the customers prefer to transfer money for its ubiquitous availability and instant transfer.

\subsection{Ranking Analysis}

Garrett Ranking Method was used to rank the reasons and main financial transactions for which respondents prefer to use online banking service.

$$
\text { PERCENT POSITION }=\quad \frac{100\left(R_{i j}-0.5\right)}{N_{j}}
$$

4.2(a) Rank Analysis of Respondents' Preference towards Online Banking

Table-4.2(a) Preference towards Online Banking

\begin{tabular}{|c|c|}
\hline Preference Towards Online Banking & RANK \\
\hline Convenient and Easy & I \\
\hline Transactions can be done faster & II \\
\hline $\begin{array}{c}\text { Online banking is a cheaper way to conduct } \\
\text { business }\end{array}$ & III \\
\hline Easier maintenance of transaction activities & IV \\
\hline Privacy & V \\
\hline Trust, Reliable, Safe and Secure & VI \\
\hline Online banking is a sign of modernity & VII \\
\hline
\end{tabular}

Interpretation: The ranking analysis revealed that Most of the respondents prefer online banking for their convenience and ease, and least of them consider online banking as a sign of modernity.

4.2(b) Rank Analysis of Main Financial Transactions Preferred by Respondents.

Table-4.2(b) Financial Transactions Preferred by Respondents

\begin{tabular}{|c|c|}
\hline Financial Transactions Preferred by Respondents & RANK \\
\hline Money transfers & I \\
\hline Pay Bills & II \\
\hline Checking of your current balance & III \\
\hline Create Fixed Deposits Online & IV \\
\hline Order a Cheque Book & V \\
\hline Request Stop Payment on a Cheque & VI \\
\hline Request a Demand Draft & VII \\
\hline
\end{tabular}

Interpretation: The ranking analysis revealed that Most of the respondents prefer online banking for transferring money, and least of them request a demand draft by online.

\subsection{Factor Analysis:}

Factor Analysis on Perceived Service Quality

Factor Analysis was used to group the numerous variables into considerable number of factors based on their similarity and inter-relationship.

$\rightarrow$ In this study, the overall Cronbach's Alpha value for measuring the perception of online banking service is 0.726 for 28 items.

$\rightarrow$ value of Kaiser-Meyer-Olkin (KMO) Measure of Sampling Adequacy is 0.540

$\rightarrow$ The Total variance explained for perceived service quality is $70.603 \%$.

\begin{tabular}{|c|c|c|c|c|c|c|}
\hline \multirow{2}{*}{ Component } & \multicolumn{3}{|c|}{ Extraction Sums of Squared Loadings } & \multicolumn{3}{|c|}{ Rotation Sums of Squared Loadings } \\
\hline & Total & $\%$ of Variance & Cumulative \% & Total & $\%$ of Variance & Cumulative \% \\
\hline 1 & 6.361 & 22.718 & 22.718 & 4.123 & 14.724 & 14.724 \\
\hline 2 & 3.301 & 11.788 & 34.506 & 2.639 & 9.424 & 24.148 \\
\hline 3 & 2.619 & 9.353 & 43.859 & 2.615 & 9.338 & 33.486 \\
\hline 4 & 2.099 & 7.498 & 51.358 & 2.509 & 8.960 & 42.446 \\
\hline 5 & 1.548 & 5.528 & 56.885 & 2.258 & 8.066 & 50.512 \\
\hline 6 & 1.378 & 4.921 & 61.807 & 2.011 & 7.181 & 57.693 \\
\hline 7 & 1.308 & 4.670 & 66.476 & 1.866 & 6.664 & 64.358 \\
\hline 8 & 1.155 & 4.126 & 70.603 & 1.749 & 6.245 & 70.603 \\
\hline
\end{tabular}

Table 4.3(a): Total Variance Explained For Perceived Service Quality 
The above table 4.3(a) depicts that the total variance explained is $70.603 \%$. The responses on 28 items measuring online banking service quality were reduced to eight sets of related factors through principal component analysis, which shows $70.603 \%$ of variance. The First Factor can be termed as Assurance with the variance of $14.724 \%$. The Second Factor indicates 9.424 variation and loads high on attributes related to Promptness of services. Followed by, the Third Factor named as Responsiveness with $9.3388 \%$ of variation. The Fourth Factor shows a variation of $8.960 \%$ and represents Efficiency. Followed by Fifth Factor named as Credibility with $8.066 \%$ variance, Sixth Factor named as Accessibility with $7.181 \%$ variance, Seventh Factor named as Compatibility with $6.664 \%$ variance and the last Eighth Factor named as Brand Image with $6.245 \%$ variance. This analysis clearly categorizes the online banking services quality based on the opinions of respondents.

\section{Determinants of Perceived Service Quality}

The factor analysis helps to extract inter-related items into one component. This analysis clearly categorizes the online banking service quality based on the opinion of respondents. Based on the loadings 28 variables (items/statements) were reduced into 8 significant factors that impact the study. The extracted items are named as Assurance, Promptness, Responsiveness, Efficiency, Credibility, Accessibility, Compatibility and Brand Image. The loading of factors based on their grouping are represented in the below table.

Table 4.3(b): Determinants of Perceived Service Quality

\begin{tabular}{|c|c|}
\hline Dimensions and Items & \multirow[t]{2}{*}{ Loadings } \\
\hline FACTOR-1 ASSURANCE & \\
\hline Feeling secured with online banking transaction & 0.832 \\
\hline Online banking is user-friendly & 0.797 \\
\hline Personal information are not misused & 0.770 \\
\hline Confident with online banking services & 0.763 \\
\hline The bank site has protection features & 0.709 \\
\hline Banks are easily accessible by telephone & 0.593 \\
\hline \multicolumn{2}{|l|}{ FACTOR-2 PROMPTNESS } \\
\hline Easy to use bank website & 0.790 \\
\hline Fund transfers are made instantly & 0.753 \\
\hline Online banking services are delivered quickly & 0.582 \\
\hline Online banking services are offered at low cost & 0.470 \\
\hline Annoying to wait in queue for bank activities & 0.453 \\
\hline \multicolumn{2}{|l|}{ FACTOR-3 RESPONSIVENESS } \\
\hline The bank responses promptly for the e-mails & 0.713 \\
\hline Satisfied with online banking services & 0.678 \\
\hline The website design is aesthetically attractive. & 0.605 \\
\hline The problems are resolved immediately & 0.465 \\
\hline Machines cannot make errors & 0.439 \\
\hline \multicolumn{2}{|l|}{ FACTOR-4 EFFICIENCY } \\
\hline Bank website is available for business & 0.861 \\
\hline $\begin{array}{l}\text { Promises of online banking services are } \\
\text { delivered correctly }\end{array}$ & 0.613 \\
\hline Accuracy in online banking transactions & 0.520 \\
\hline FACTOR-5 CREDIBILITY & \\
\hline $\begin{array}{l}\text { There are chances of fraud and forged } \\
\text { transactions via online banking services }\end{array}$ & 0.823 \\
\hline
\end{tabular}

Interpretation: The result of this study reveals that respondents are influenced by the following factors such as Assurance, Promptness, Responsiveness, Efficiency, Credibility, Accessibility, Compatibility and Brand Image. The loading of factors ranges from 0.832 to 0.593 for Assurance, Promptness from 0.790 to 0.453 , Responsiveness from 0.713 to 0.439 , Efficiency from 0.520 to 0.861 , Credibility from 0.823 to 0.773 , Accessibility from 0.809 to 0.801 , Compatibility from 0.826 to 0.540 , Brand Image from 0.834 to 0.745 . Hence, the respondents consider these factors to be predominant for the adoption of online banking service.

\subsection{ANOVA - Analysis Of Variance on Preference of Online Banking Usage and Level of Satisfaction}

One-Way Analysis of Variance was performed to determine whether Preference of Online Banking Usage significantly differs across the Satisfaction Level of the respondents. The results of the analysis were presented in the following table.

H0: There is no significant mean difference among Level of Satisfaction of Respondents with respect to Preference of Online Banking Usage

H1: There is significant mean difference among Level of Satisfaction of the Respondents with respect to Preference of Online Banking Usage

Table 4.4(a) ANOVA on Preference of Online Banking Usage vs. Level Of Satisfaction

\begin{tabular}{|c|c|c|c|c|}
\hline $\begin{array}{c}\text { Preference of Net } \\
\text { Banking }\end{array}$ & Mean & $\begin{array}{c}\text { Std. } \\
\text { Deviation }\end{array}$ & F Value & Sig. \\
\cline { 1 - 3 } Always & 1.61 & 0.492 & & \\
\cline { 1 - 3 } Often & 2.17 & 0.570 & \multirow{2}{*}{20.544} & \multirow{2}{*}{0.000} \\
\cline { 1 - 3 } Sometimes & 2.27 & 0.452 & & \\
\hline Rare & 3.00 & 0.000 & & \\
\hline Total & 1.91 & 0.601 & & \\
\hline
\end{tabular}

Interpretation: From the above table, the result reveals that there is significant mean difference among the respondents. Preference of Online Banking Usage significantly differ 
across Level of Satisfaction of the respondents $[\mathrm{F}=20.544 ; \mathrm{p}$ $=0.000, \mathrm{p}<0.05]$. Since, the $\mathrm{p}$ value is significant at $5 \%$ level. The null hypothesis is rejected and the alternate hypothesis is accepted. It is concluded that there is significant mean difference between Preference of Online Banking Usage significantly differ across the Level of Satisfaction of the respondents which means customers are highly satisfied by using online banking services.

\section{SUGGESTIONS AND RECOMMENDATIONS}

The convenience of online banking has proved popular among customers. There is a requisite to offer personalized as well as enhanced online banking services to customers. Banks must identify the customer's attitude in relation with the acceptance of online banking. It is very important to provide accurate, friendly and valuable customer service to the online banking users. The chief suggestion and recommendation is that banks should improve the degree of trust among bank websites and the users (customers). For creating trust and improving the usage, the following strategies must be taken up by the banks:

$\checkmark$ The banks should concentrate on creating awareness to online baking users and non-users and guarantee that similar to conventional method of banking, online banking is also reliable, secured and trustworthy.

$\boldsymbol{}$ Customers must be educated with the computing skills and training should be conducted by the bank professionals on online banking services and its features, so that people learn the usage of online banking facilities.

Banks should communicate to the people that using online banking helps in cost saving and encourage online banking transaction by reducing the transaction cost.

Banks should ensure that that customers' personal and financial information are stored safely and will be kept confidentially.

$\checkmark$ Banks should create trust in the minds of their customers by delivering the online services with high security.

Consequently, the banks should design their website to tackle the security and privacy issues. Government should scrutinize on the cyber-crime and frame legal and regulatory rules pertaining to online banking hurdles such as hacking and fraudulences which will subsequently improve confidence level among people and will eventually elevate the usage of online banking.

\section{CONCLUSION}

Customers most commonly use the services like fund transfers and online payment such as utility bills, taxes, duties, insurance premium, etc. In addition, the issue of security in online banking is still a major factor in customers' reluctance to adopt online banking services. Online banking service providers need to understand the importance of transparency, accountability, reduction of fraud and more importantly economic growth and development. Furthermore, the quality of web design and content, convenience and speed has a relationship with customer satisfaction towards online banking. In the forthcoming years online banking will be the only accepted and preferred mode of banking service. Government of India has taken more initiatives such as Cashless Economy, Digital India to build-up the use of online banking. In India, the utilization of smart phones, computers, laptops and online connection are tremendously increasing; this indicates that people are using online services. Most of the banks have their mobile apps and people are handling most of their transactions through online services, this reveals that as the scope of online banking are enhanced. Hence, it can be concluded that there is no doubt that in the near future online banking will be the preferred mode of banking and undeniably overcome traditional banking.

\section{LIMITATIONS OF THE STUDY}

o Convenient Sampling has been used in the study and it has its own limitations

o The data collected is primary and hence there may be the personal bias of the respondents.

o The study is restricted to the respondents of Chennai City. Hence, the results arrived from the study may not be applicable to other geographical locations

o Perception of customers changes continuously based on the availability of information.

o Some respondents were reluctant to divulge personal and banking information.

\section{REFERENCES}

1. Hua, G. (2009). An experimental investigation of online banking adoption in China. Journal of Internet Banking and Commerce, 14(1), 1 -12 .

2. Vichuda, N. P., \& Serap, E. (2001). An empirical investigation of the Turkish consumers' acceptance of Internet banking services. International Journal of Bank Marketing, 19(4), 156-165.

3. Laforet, S., \& Li, X. (2005). Consumers' attitudes towards online and mobile banking in China. International Journal of Bank Marketing, 23(5), 362-380

4. Awamleh, R., \& Fernandes, C. (2005). Internet Banking: an empirical investigation into the extent of adoption by banks and the determinants of customer satisfaction in the United Arab Emirates. Journal of Internet Banking and Commerce, 10, 1-12.

5. Yiu, C. S., Grant, K., \& Edgar, D. (2007). Factors affecting the adoption of Internet Banking in Hong Kong-implications for the banking sector. International Journal of Information Management, 27(5), 336-351.

Websites

6. www.google.co.in

7. www.investopedia.com

8. www.wikipedia.com

9. www.scribd.com

10. www.academia.edu

11. www.rbi.org.in

12. www.npci.org.in 


\section{AUTHORS PROFILE}

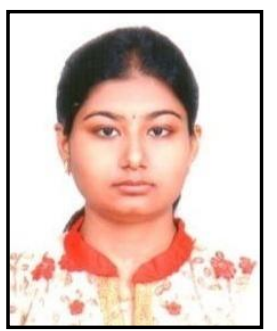

C.B.Pavithra, currently pursuing doctoral research in the area of digital banking in the Department of Commerce, S.D.N.B.Vaishnav College for Women, Affiliated to the University to Madras, Chennai, under the guidance of Dr.A.C.Ranganayaki. She has secured First Class with Distinction in both M.Com \& M.Phil (Specialization in Banking). And she has also cleared the Tamil Nadu State Eligibility Test (TNSET) for the post of Assistant Professor. She has participated and presented her research papers in many National and International Conferences. She has also taken part in various workshops and seminars. She has published her research papers in Regional, National and International Conferences in peer reviewed and referred journals. Her areas of interest in research include online/digital banking, digital payment systems. She has a keen interest in exploring the modernization of payment systems and impact of technology involved in consumer payment systems. She has received the best paper award for the paper titled "Types, Opportunities and Challenges of Digital Payment Systems in India." in an International Conference.

Dr.A.C.Ranganayaki, is presently working as an Assistant Professor, in the Department of Commerce, S.D.N.B.Vaishnav College for Women, Affiliated to the University to Madras, Chennai. She holds Ph.D in Commerce, M.Phil with specialization in Marketing, M.Com and B.Ed. She has got more than 3 decades of teaching experience. She has been handling subjects relating to accounts and finance, statistics and operational research and human resource management. She has published numerous research papers in peer reviewed journals. She has attended many National and International Conferences, Seminars and Workshops. She has been assisting many events, seminars, workshops and conferences. She represented as a University Nominee for introducing and reviewing new courses in various colleges affiliated to University of Madras. She is presently working as a Chief for Central Valuation, University of Madras. 